\title{
IL-10 secreting regulatory $B$ cells are potent arbiters of autoimmunity in both mouse and man
}

\author{
Claudia Mauri $^{*}$, Fabian Flores-Borja ${ }^{1}$, Paul A Blair ${ }^{2}$, Natalie A Carter ${ }^{1}$ \\ From 6th European Workshop on Immune-Mediated Inflammatory Diseases \\ Nice, France. 23-25 November 2011
}

\section{Background}

The existence of B cells with a suppressive function, namely regulatory $B$ cells (Bregs), has been demonstrated in a number of murine models of autoimmunity in the last decade. Adoptive transfer of Bregs has been shown to inhibit the development of several autoimmune diseases via the release of Interleukin-10 (IL-10).

\section{Aim}

To ascertain the role of IL-10 secreting Bregs during the induction and progression of experimental autoimmune disease in mice.Then to use this information to identify an equivalent subset in man and assess the impact of Bregs on inflammatory responses and disease severity.

\section{Materials and methods}

We generated chimeric mice that lack IL-10 specifically in their B cells and used this model to investigate the role of endogenous B cell- derived IL-10 during inflammatory arthritis. Moreover, we have identified and assessed the role of Bregs in healthy individuals as well as patients with rheumatological disorders.

\section{Results}

We have recently investigated the mechanisms utilized by endogenous Breg at the cellular level in an experimental model of arthritis and shown that the IL-10 produced by Bregs is important in the maintenance of regulatory $\mathrm{T}$ cells (Tregs) whilst suppressing Th1 and Th17 responses. Indeed chimeric mice specifically lacking IL-10 producing $\mathrm{B}$ cells (IL-10 ${ }^{-1-} \mathrm{B}$ cell) developed an exacerbated arthritis, displayed reduced absolute numbers of FoxP3+ Tregs, and a marked increase in inflammatory Th1 and Th17 cells compared to chimeric wild type B cell mice. In addition

${ }^{1}$ University College London, Division of Medicine, Centre for Rheumatology Research, The Rayne Institute, London, UK

Full list of author information is available at the end of the article we extended our results from experimental models of arthritis to humans and identified an equivalent population of Breg that produce IL-10, inhibit $\mathrm{CD} 4^{+} \mathrm{T}$ effector responses and convert effector $\mathrm{CD} 4+\mathrm{T}$ cells into regulatory $\mathrm{T}$ cells.

\section{Conclusions}

Our work has demonstrated the importance of Bregs in controlling inflammatory responses and preventing autoimmunity in both experimental arthritis in mice $[1,2]$ and patients with rheumatological disorders [3]. This presentation reports the function of this pivotal B cell subset and describes Bregs in the context of healthy individuals as well as in patients with systemic lupus erythematosus and rheumatoid arthritis. The impact of altered cellular function within the Breg compartment on disease outcome will be also discussed $[4,5]$.

\section{Acknowledgements}

This work was supported by the Nuffield Foundation Oliver Bird Rheumatism Programme, Arthritis Research UK, Lupus UK and Wellcome Trust.

\section{Author details}

'University College London, Division of Medicine, Centre for Rheumatology Research, The Rayne Institute, London, UK. ${ }^{2}$ Medical Research Council Centre for Transplantation, Dept. of Nephrology and Transplantation, Guy's Hospital, Kings College London, London, UK.

Published: 23 November 2011

\section{References}

1. Carter NA, Vasconcellos R, Rosser EC, Tulone C, Muñoz-Suano A, Kamanaka M, Ehrenstein MR, Flavell RA, Mauri C: Mice lacking endogenous IL-10-producing regulatory $B$ cells develop exacerbated disease and present with an increased frequency of Th1/Th17 but a decrease in regulatory T cells. J Immunol 2011, 186:5569-5579.

2. Evans JG, Chavez-Rueda KA, Eddaoudi A, Meyer-Bahlburg A, Rawlings DJ, Ehrenstein MR, Mauri C: Novel suppressive function of transitional 2 B cells in experimental arthritis. J Immunol 2007, 178:7868-7878.

3. Blair PA, Noreña $L Y$, Flores-Borja F, Rawlings DJ, Isenberg DA, Ehrenstein MR, Mauri C: CD19(+)CD24(hi)CD38(hi) B cells exhibit regulatory capacity in 
healthy individuals but are functionally impaired in systemic Lupus

Erythematosus patients. Immunity 2010, 32:129-140

4. Mauri C: Regulation of immunity and autoimmunity by B cells. Curr Opin Immunol 2010, 22:761-767.

5. Mauri C, Blair PA: Regulatory B cells in autoimmunity: developments and controversies. Nat Rev Rheumatol 2010, 6:636-643.

doi:10.1186/1479-5876-9-S2-112

Cite this article as: Mauri et al:: IL-10 secreting regulatory $\mathrm{B}$ cells are potent arbiters of autoimmunity in both mouse and man. Journal of Translational Medicine 2011 9(Suppl 2):112.

Submit your next manuscript to BioMed Central and take full advantage of:

- Convenient online submission

- Thorough peer review

- No space constraints or color figure charges

- Immediate publication on acceptance

- Inclusion in PubMed, CAS, Scopus and Google Scholar

- Research which is freely available for redistribution

Submit your manuscript at www.biomedcentral.com/submit 